\title{
Imunitas Negara Asing Di Depan Pengadilan Nasional Dalam Kasus Pelanggaran HAM Yang Berat Konsekuensi Hukum Jus Cogens Terhadap Imunitas Negara
}

\author{
Sefriani \\ Fakultas Hukum Universitas Islam Indonesia \\ Jl. Tamansisawa No. 158 Yogyakarta \\ sefriani@fh.uii.ac.id
}

\begin{abstract}
Gross violation on human right has been occurred at many countries. Almost all of the perpetrators are state .In international law foreign state has immunity before national court. Developing of international law showed that in one side gross violation on human right is prohibited and has a status as jus cogens, peremptory nom under international law. However foreign state immunity before national court is fundamental right. International law doesn't strictly and clearly governed legal consequences jus cogens norm over gross violation on human right. Some of national court remaining recognized state immunity to foreign state with some legal reason. However others national court denied that immunity.
\end{abstract}

Key words : law's consequences, state's immunity, the International law.

\begin{abstract}
Abstrak
Pelanggaran besar-besaran terhadap hak asasi manusia telah terjadi di banyak negara. Hampir semua jenis tindakan yang membahayakan (mengancam) yang tercantum di dalam hukum internasional malah dilakukan oleh negara-negara asing yang memiliki kekebalan hukum. Berdasarkan perkembangan terhadap hukum internasional menunjukkan bahwa pada satu sisi, segala tindakan yang melanggar hak asasi Manusia adalah dilarang (tidak benar berdasarkan hukum) dan memiliki status sebagai jus cogens, sesuatu yang baku berada di bawah hukum internasional. Meskipun demikian, hak kebal hukum yang dimiliki oleh suatu negara asing juga sekaligus dibenarkan. Hukum internasional tidak secara tegas dan jelas mengatur hukuman (konsekuensi hukum)/ norma jus cogens terhadap kejahatan/ pelanggaran terhadap hak asasi manusia. Beberapa pengadilan nasional mengenali/mengakui/menerima hak kekebalan hukum beberapa pada negara asing dengan argumen- argumen hukum yang logis. Namun demikian, beberapa negara lain menolak adanya kekebalan hukum yang dimiliki oleh beberapa negara asing.
\end{abstract}

Kata kunci : konsekuensi Hukum, imunitas negara, hukum internasional. 


\section{Pendahuluan}

Kurangnya kepastian hukum (lack of certainty) merupakan salah satu kelemahan hukum internasional yang banyak disorot oleh para pakar hukum internasional. Martin Dixon dalam bukunya Textbook on international law mengemukakan bahwa banyak sengketa antar negara yang timbul akibat tidak jelasnya aturan hukum internasional daripada kesengajaan negara-negara tersebut untuk melakukan sesuatu yang ilegal. ${ }^{1}$

Salah satu ketidakjelasan yang membawa pada ketidakpastian hukum tersebut adalah pada masalah hierarkhi ketentuan-ketentuan hukum internasional. Mochtar Kusumaatmadja mengemukakan bahwa urut-urutan macam-macam sumber hukum dalam Pasal 38 (1) Statuta Mahkamah Internasional tidak menggambarkan urutan pentingnya masing-masing sumber hukum tersebut. ${ }^{2}$ Dengan demikian tidak dapat dikatakan bahwa perjanjian internasional kedudukannya lebih tinggi dari hukum kebiasaan internasional meskipun dalam pasal tersebut Perjanjian (treaty) disebutkan pada urutan pertama sedangkan hukum kebiasaan internasional (international customary law) pada urutan kedua.

Ketidakjelasan masalah hierarkhi ini tentu sangat berpotensi menimbulkan persoalan mana yang harus diutamakan bilamana sumber hukum yang satu bertentangan dengan sumber hukum yang lain, mana yang harus diutamakan. Contoh yang dapat dikemukakan dalam kaitannya dengan hal ini kasus Sulaiman Al Adsani vs Pemerintah Inggris yang diputus oleh European Court of Human Right Tahun 2001 yang lalu. ${ }^{3}$

Kasus ini bermula ketika Sulaiman Al-Adsani, seorang warga Inggris ditangkap secara paksa tanpa melalui prosedur hukum, bahkan disiksa oleh pasukan pemerintah Kuwait saat yang bersangkutan mengunjungi Kuwait tak lama setelah berakhirnya Perang Teluk I. Al-Adsani dituduh menyebarluaskan kaset video penyimpangan seksual Sheikh Jaber Al Sabah Al Saud, saudara Emir Kuwait kepada

\footnotetext{
${ }^{1}$ Martin Dixon, Textbook on international law, Blackstone Press Limited, London, Fourt edition, 2000, hlm. 12

${ }^{2}$ Mochtar Kusumaatmadja, Pengantar Hukum Internasional, Buku I Bagian Umum, Jakarta, Binacipta, cetakan keempat, 1982, hlm. 108

3 Sefriani, 2004,'Imunitas Negara Asing di forum Pengadilan Naisonal Dalam kasus Pelanggaran HAM berat : Studi kasus Putusan The European Court on Human Right dalam Al-Adsani v The United Kingdom 21 Nopember 2001 App. No. 35763/97. Penelitian pada Departemen Hukum Internasional Fakultas Hukum UII. Dalam penelitian ini yang diteliti adalah pertimbangan-pertimbangan hukum yang digunakan hakim ECHR dalam memberikan imunitas pada Kuwait.
} 
publik. Dalam perjalanan ke tahanan negara, Al-Adsani ditodong dan dipukul dengan pistol. Selanjutnya ia mengalami berbagai penyiksaan seperti kepalanya dibenamkan di kolam renang, beberapa bagian tubuhnya dibakar serta dimasukkan ke ruangan kecil yang penuh asap yang sangat menyulitkan ia untuk bernafas (AlAdsani v United Kingdom, App. No.35763/97, November, 21, 2001). ${ }^{4}$ Sekembalinya ke Inggris, Al-Adsani mengajukan kasusnya, menuntut tanggung jawab dan ganti rugi dari Pemerintah Kuwait ke Pengadilan Inggris (England's High Court). Pengadilan menolak kasus ini dengan alasan kurang cukup memiliki yurisdiksi. Kuwait berhak atas imunitas negara asing berdasarkan UK State Immunity Act 1978. Al-Adsani harus menerima kekecewaan yang sama di pengadilan tingkat banding, dikalahkan dengan dasar imunitas negara. ${ }^{5}$

Tidak puas atas penolakan ini, Al-Adsani mengajukan pemerintahnya ke European Court of Human Right (ECHR). Di depan ECHR pihak Al-Adsani mengemukakan bahwa dengan memberikan imunitas pada Kuwait maka Inggris telah gagal melindungi warganya sendiri dari penyiksaan (torture) dan prinsip pengingkaran terhadap keadilan (denial of justice principle), dimana ia tidak mendapatkan hakhaknya dalam proses hukum. Sayang sekali di pengadilan inipun Al-Adsani harus menerima kekalahan dengan alasan yang sama. Meskipun memberikan imunitas pada Kuwait, Pemerintah Inggris dinyatakan tidak melanggar hukum internasional. ${ }^{6}$

Hal yang menarik dari putusan ECHR ini adalah tampilnya Teori hierarkhi normatif (The Normative Hierarchi Theory) dalam proses persidangan. Pihak pengacara Al-Adsani menyatakan bahwa berdasarkan teori hierarkhi normatif, imunitas negara akan dicabut (abrogated) ketika negara melanggar hak asasi manusia yang merupakan jus cogens. Hal ini dikarenakan bahwa state immunity bukan jus cogens sehingga kedudukannya lebih rendah dari larangan melakukan penyiksaan (torture) yang mempunyai karakteristik khusus dalam hukum internasional. ${ }^{7}$

Hal yang menarik pula dari putusan ECHR ini adalah bahwa putusan diambil dengan perbandingan suara 9:8. Mayoritas hakim di satu sisi mengakui bahwa larangan penyiksaan memiliki status jus cogens. Ada beberapa judicial statement yang

${ }^{4}$ Perlakuan-perlakuan buruk yang diterima Al-Adsani selengkapnya dapat ditemukan dalam Al-Adsani v United Kingdom, App. No.35763/97, paras 9-13, November, 21, 2001, http://www.echr.coe.int/eng/judgments, htm,

${ }^{5}$ Caplain, Lee. M, "State Immunity, Human Rihgts, and Jus Cogens: a Critique of the Normative Hierarchy Theory", American Journal of International Law, Vol. 97, 2003, hlm. 741

${ }^{6}$ Ibid.

${ }^{7}$ Ibid., hlm.746 
menempatkan larangan penyiksaan sebagai jus cogens menurut mereka. Dalam kasus Furundza yang diputus oleh The International Criminal Tribunal for the former Yugoslavia, pengadilan dengan tegas menetapkan bahwa larangan penyiksaan memiliki status sebagai jus cogens atau peremptory norm, menikmati kedudukan yang lebih tinggi dalam hierarkhi internasional dibandingkan treaty law atau juga 'ordinary' customary law. Pernyataan serupa juga dapat ditemukan dalam kasus-kasus lain di pengadilan internasional maupun nasional, termasuk di The House of Lords dalam kasus ex Parte Pinochet (Al-Adsani v United Kingdom, App. No. 35763/97, November, 21, 2001). Larangan penyiksaan (torture) termasuk dalam hak-hak asasi manusia yang tidak dapat dikurangi (non derogable) serta intisari dari hak asasi manusia (hard core rights) atau hak yang paling mendasar yang harus dihormati baik dalam keadaan damai maupun dalam keadaan perang sebagaimana juga hak hidup, larangan perbudakan jaminan peradilan dan prinsip perlakuan non diskriminasi. ${ }^{8}$ Namun demikian, di sisi lain mayoritas hakim ECHR tersebut menyatakan tidak mampu melihat (unable to discern) ada instrumen internasional yang memiliki status jus cogens pula yang memberikan dasar hukum bahwa negara tidak lagi berhak menikmati imunitas atas gugatan perdata di pengadilan nasional negara lain untuk kasus penyiksaan yang terjadi di wilayahnya. Secara khusus disebutkan oleh ECHR bahwa tidak ada the primary international instrument, yaitu Pasal 5 Universal d Declaration of Human Rights, Pasal 7 The International Covenant on Civil and Political Rights, juga Pasal 2 dan 4 UN Convention Against Torture and Other Cruel, Inhuman and Degrading Treatment or Punishment yang mengatur mengenai hilangnya imunitas negara tersebut. Dengan demikian menurut mayoritas hakim tersebut tidak ada pelanggaran hukum internasional yang telah dilakukan Inggris, meskipun negara ini memberikan imunitas pada negara Kuwait sebagai pelaku penyiksaan (torture).

Putusan ECHR ini banyak menuai kritik, dianggap sebagai preseden buruk bagi kasus-kasus pelanggaran HAM. Putusan ini dikawatirkan akan mendorong lebih banyak terjadinya pelanggaran HAM oleh negara. Minoritas hakim ECHR dalam dissenting opinion masing-masing pada prinsipnya sependapat dengan pihak pengacara Al-Adsani, bahwa dengan memiliki status jus cogens maka segala hambatan prosedur hukum seperti keberadaan prinsip imunitas negara harus dicabut untuk

\footnotetext{
${ }^{8}$ Andrey Sudjatmiko, "Perlindungan HAM dalam Hukum HAM dan Hukum Humaniter Internasional", dalam kumpulan tulisan, Pusat Studi Hukum Humaniter, Jakrta, Usakti, 1999, hlm. 103. Lihat juga lihat Arlina permanasari, dkk, Pengantar Hukum Humaniter, Jakrta, ICRC, 1999, hlm. 341-342
} 
tegaknya aturan jus cogens tersebut. Dari paparan kasus putusan Al-Adsani ini, dapat disimpulkan bahwa ketidak sepahaman mayoritas hakim (9 orang) dengan minoritas hakim (8 orang), muncul akibat tidak adanya aturan yang jelas mengenai hierarki dalam hukum internasional.

Doktrin imunitas negara dalam hukum internasional telah berkembang sedemikian rupa, dari doktrin imunitas absolut sampai pada imunitas yang terbatas (restriktif). Dalam disertasinya," Perkembangan penerapan imunitas kedaulatan negara dalam penyelesaian perkara di forum pengadilan: studi perbandingan atas praktek Indonesia" tahun 1995, Yudha Bakti Ardiwisastra mengemukakan, bahwa doktrin imunitas restriktif membagi tindakan negara dalam iure gestionis dan iure imperii. Hanya dalam hal tindakan negara tergolong juree imperii negara memiliki imunitas di depan forum pengadilan nasional asing. Adapun ketika negara masuk ke wilayah perdata, negara melakukan transaksi komersil atau bisnis, maka tidaklah lagi berlaku imunitas bagi dirinya. ${ }^{9}$ Namun demikian, Yudha Bakti hanya menyinggung imunitas dalam kaitannya dengan iure imperi dan iure gestionis, sama sekali tidak menyinggung masalah imunitas dalam kaitannya dengan pelanggaran HAM yang berat.

Pembahasan mengenai imunitas negara asing di depan forum pengadilan nasional dalam kasus HAM yang berat telah dirintis oleh peneliti dalam penelitian sebelumnya. Dalam penelitian tersebut peneliti hanya meneliti pertimbanganpertimbangan hukum yang digunakan oleh hakim ECHR yang menjustifikasi putusan pengadilan Inggris memberikan imunitas pada Kuwait meskipun terbukti melakukan pelanggaran HAM yang berat pada warga Inggris di Kuwait.

Putusan ECHR 2001 dalam kasus Al-Adsani, yang menjadi kajian peneliti dalam penelitian tersebut, tentu tidak dapat digunakan untuk menggeneralisasi bahwa imunitas negara merupakan hukum kebiasaan internasional yang sangat fundamental, yang akan tetap ada atau tidak dipengaruhi oleh adanya pelanggaran jus cogens (peremptory norms). Kajian terhadap putusan-putusan pengadilan internasional, regional, maupun nasional dalam kasus serupa tentu sangat diperlukan untuk dapat membuat suatu generalisasi atau kesimpulan mengenai konsekuensi hukum jus cogens terhadap imunitas negara dalam kasus pelanggaran terhadap HAM yang berat.

${ }^{9}$ Yudha Bakti Ardhiwisastra, Perkembangan Penerapan Imunitas Kedaulatan Negara dalam Penyelesaian di Forum Pengadilan:Studi perbandingan atas praktek Indonesia di Forum Pengadilan Asing, disertasi, PPS Unpad Bandung, 1995, hlm. 442 


\section{Rumusan Masalah}

Dari paparan yang telah diuraikan dalam pendahuluan di atas, maka permasalahan yang akan dikaji adalah sebagai berikut:

1. Apakah imunitas negara di depan pengadilan nasional asing merupakan suatu hak yang fundamental yang dimiliki oleh suatu negara berdaulat berdasar hukum internasional?

2. Mengapa dalam banyak kasus yang diputus pengadilan nasional maupun internasional pengadilan tetap mengakui adanya imunitas negara asing di depan pengadilan nasional sekalipun dalam kaitannya dengan pelanggaran HAM yang berat?

3. Bagaimana hierarkhi antara imunitas negara di satu sisi dengan pelanggaran terhadap HAM yang berat di sisi lain dalam hukum internasional?

\section{Tujuan Penelitian}

Adapun tujuan penelitian ini adalah:

1. Untuk mengetahui apakah imunitas negara di depan pengadilan nasional asing merupakan suatu hak yang fundamental yang dimiliki oleh suatu negara berdaulat berdasar hukum internasional.

2. Untuk mengetahui mengapa dalam banyak kasus yang diputus pengadilan nasional maupun internasional pengadilan tetap mengakui adanya imunitas negara asing di depan pengadilan nasional sekalipun dalam kaitannya dengan pelanggaran HAMyang berat.

3. Untuk mengetahui hierarkhi antara imunitas negara di satu sisi dengan pelanggaran terhadap HAM yang berat di sisi lain dalam hukum internasional.

\section{Metode Penelitian}

Penelitian ini adalah penelitian yuridis normatif yang mengkaji berbagai peraturan perundangan nasional tentang HAM, berbagai peraturan perundangan di berbagai negara tentang imunitas negara asing, konvensi internasional tentang HAM, putusan pengadilan nasional, regional maupun internasional tentang imunitas negara asing di depan pengadilan nasional dalam kaitannya dengan pelanggaran HAM yang berat. 
Adapun pendekatan yang digunakan adalah pendekatan perundang-undangan (statute approach), pendekatan konsep (conceptual approach), pendekatan perbandingan (comparative approach), dan pendekatan kasus (case approach).

Selanjutnya bahan hukum yang digunakan meliputi bahan hukum primer, sekunder dan tersier. Bahan hukum yang diperoleh dari hasil studi kepustakaan selanjutnya dikumpulkan, dikelompokkan sesuai variabel masing-masing, untuk selanjutnya dianalisis secara kualitatif. Selanjutnya penelitian akan disajikan dalam bentuk deskriptif.

\section{Hasil Penelitian}

\section{Imunitas Negara di Depan Forum Asing merupakan hak yang fundamental}

Doktrin imunitas negara adalah suatu doktrin yang mengijinkan suatu negara menuntut imunitas atau kekebalan di depan pengadilan nasional negara asing berkaitan dengan penerapan hukum lokal negara asing yang bersangkutan. Negara dalam berbagai bentuk penampakan seperti departemen pemerintah, pejabat negara, kepala negara mampu melepaskan diri dari penerapan hukum nasional yang dilakukan oleh pengadilan nasional negara lain. ${ }^{10}$

Pengakuan umum terhadap imunitas negara didasarkan atas konsep kedaulatan. Karena negara adalah subyek yang merdeka dan sejajar satu sama lain maka tidak dapat ditundukkan di bawah yurisdiksi negara lain tanpa persetujuannya. Keberadaan imunitas negara menurut Alina Kaczowska tidak dapat dilepaskan dari 2 prinsip utama, ${ }^{11}$ yaitu prinsip Par in parem non habet jurisdiction, dan prinsip non intervention terhadap masalah dalam negeri negara lain. Pada prinsip yang pertama, legal persons dari subyek-subyek yang sejajar posisinya tidak dapat memperoleh penyelesaikan sengketa di pengadilan nasional salah satu dari mereka. Prinsip ini didasari oleh prinsip persamaan kedaulatan dan kemerdekaan. Dengan demikian pihak yang berdaulat dari suatu negara asing dikecualikan dari yurisdiksi pengadilan nasional. Meskipun demikian dimungkinkan adanya penanggalan imunitas sehingga pengadilan nasional dapat memiliki yurisdiksi. ${ }^{12}$ Adapun prinsip yang kedua

\footnotetext{
${ }^{10}$ Martin Dixon, Op.Cit., hlm. 174

${ }^{11}$ Alina Kaczorowska, Public International Law, London, Old Bailey Press, 2002, hlm. 139

${ }^{12}$ Ibid., hlm.140
} 
menegaskan larangan untuk ikut campur terhadap urusan dalam negeri negara lain. Mengadili negara lain di depan pengadilan nasional akan dianggap melanggar prinsip ini.

Sejak pertengahan abad 19, prinsip imunitas kedaulatan telah diterima sebagai praktek umum di kebanyakan negara-negara modern di Eropa dan Amerika. Mayoritas pengadilan mereka menyetujui bahwa negara-negara asing harus dikecualikan dari pelaksanaan yurisdiksi teritorial setiap pengadilan nasional. Mereka juga mengakui bahwa dasar pengecualian tersebut berada dalam kedaulatan negara-negara itu sendiri. Dengan kata lain, dapat dikatakan bahwa dasar imunitas dalam hukum internasional dapat ditemukan dalam prinsip-prinsip kedaulatan, kemerdekaan, persamaan derajat, penghormatan terhadap negara-negara asing, ekstra teritorialitas, sopan santun dan fungsi diplomatik. ${ }^{13}$ Tujuan keberadaan doktrin imunitas negara untuk meningkatkan sopan santun dan hubungan baik antar negara melalui penghormatan atas kedaulatan negara lain.

Kaedah imunitas kedaulatan negara menurut Starke mempunyai 2 aspek penting, yaitu imunitas dari proses pengadilan dan imunitas berkenaan dengan harta benda yang dimiliki negara asing atau pemegang kedaulatan negara asing. ${ }^{14}$ Imunitas dari proses pengadilan berarti bahwa pengadilan tidak dapat melakukan proses menuntut negara asing atau menarik negara-negara asing menjadi pihak dalam proses perkara yang bertentangan dengan kehendak mereka, baik yang menyangkut pemrosesan terhadap personalitas atau yang bertujuan untuk memulihkan harta kekayaan khusus atau kerugian-kerugian. ${ }^{15}$

Dari apa yang dipaparkan di atas, nampak bahwa sampai saat ini imunitas negara asing masih merupakan prinsip yang fundamental, diakui dan diterima oleh masyarakat internasional. Negara wajib memberikan imunitas pada negara asing di depan forum nasional mereka. Pemberian imunitas ini sangat penting artinya, bertujuan untuk sopan santun, menghormati kedaulatan negara lain serta menjaga hubungan baik dengan negara lain. Mengadili negara lain di depan forum nasional akan dianggap merendahkan harkat dan martabat negara tersebut. Dengan mengadili negara asing di forum nasional seolah meletakkan posisi sebuah negara merdeka yang semestinya punya kedudukan sejajar dengan negara merdeka lain negara di

\footnotetext{
${ }^{13}$ O’Connell, International Law, Vol II, 2th edition, London, Stevens \& Sons Ltd, 1970, hlm. 842-844

${ }^{14}$ JG. Starke, Pengantar Hukum Internasional, Edisi kesepuluh, Buku I, dialihbahasakaan oleh Bambang Iriana Djajatmmaadja, Jakarta, Sinar Grafika, 1992, hlm.282

${ }^{15}$ Ibid.
} 
bawah posisi negara yang mengadili. Meskipun demikian, praktek negara-negara juga menunjukkan bahwa saat ini yang berlaku adalah teori imunitas terbatas yang membedakan tindakan negara menjadi jure gestionis dan jure imperii. Seiring dengan menguatnya penghormatan terhadap HAM pembatasan imunitas negara asing di depan forum nasional tidak lagi terbatas pada tindakan komersiil semata tetapi juga terhadap tindakan yang mengakibatkan kematian atau kerugian lainnya pada seseorang dimana tindakan itu terjadi seluruhnya atau sebagian di negara forum dan dengan syarat tindakan itu dapat dilimpahkan (attributable) pada negara asing itu.

\section{Berbagai putusan pengadilan terkait pelanggaran HAM berat dan imunitas negara}

1. Putusan-putusan pengadilan yang menolak adanya imunitas negara
a) Kasus Ferrini v Jerman
b) Prefecture of Voiotia v. Federal Republic of Germany (the Distomo massacre case)
c) Kasus Furundzija
d) Princz v. Federal Republic of Germany

2. Putusan-putusan pengadilan yang memberikan imunitas Negara
a) Al-Adsani v Kuwait
b) Bouzari v Iran(App no 31253/96).
c) Ron Jones v Saudi Arabia.
d) McElhinney $v$ Ireland,
e) Kasus the Arrest Warrant of 11 April 2000 (Democratic Republic of the Congo v. Belgium), 14 February 2002

Dari analisa kasus-kasus di atas dapat disimpulkan bahwa yang mendorong pengadilan tidak memberikan imunitas antara lain :

a) Imunitas negara dewasa ini mengalami pengikisan terhadap norma-norma jus cogens yang memberi perlindungan pada HAM yang fundamental. Memberikan imunitas negara dalam hal terjadinya pelanggaran jus cogens sama dengan menghambat perlindungan HAM yang fundamental serta membahayakan nilainilai universal dan kepentingan komunitas seluruh bangsa.

b) Yurisdiski universal dapat diperluas pada tindakan perdata sebagai akibat kerugian yang muncul dari dilakukannya kejahatan internasional. 
c) Dikotomi tradisional antara tindakan jure imperii dan jure gestionis untuk menilai aktifitas negara sudah tidak mencukupi lagi dalam kasus-kasus tertentu seperti kasus pelanggaran HAM yang berat. Beberapa negara telah mengubah undangundang imunitas negara asing di forum nasional mereka dengan memprioritaskan pelanggaran HAM yang berat atas imunitas negara.

d) Tindakan yang masuk kategori kejahatan internasional tidak dapat dianggap sebagai tindakan resmi pejabat negara dalam rangka melaksanakan fungsinya ataupun tindakan pihak yang berdaulat untuk tujuan memperoleh imunitas.

e) Suatu Kejahatan internasional harus dipandang sebagai tindakan yang salah dalam kapasitas pribadi, sehingga Functional Immunity harus dicabut dalam hal kejahatan internasional.

f) Sifat HAM yang fundamental sebagai jus cogens, peremptory norms, melindungi HAM diutamakan atas hukum kebiasaan internasional yang biasa ('simple' customary rules) seperti pemberian imunitas negara. Berbagai tindakan pelanggaran HAM yang berat termasuk di dalamnya kejahatan internasional adalah tindakan yang melanggar atau tidak konsisten dengan peremptory norm sehingga tuntutan imunitas negara tidak dapat diberikan atau null and void.

g) Teori normative hierarchi (or trumping argument) menyatakan bahwa norma HAM mempunyai status peremptory otomatis diutamakan apabila konflik dengan norma yang lain seperti imunitas negara.

h) Hanya tindakan negara yang masuk kategori jure imperi yang memperoleh imunitas. Pelanggaran HAM yang berat bukanlah jure imperii melainkan penyalahgunaan kedaulatan negara, pelanggaran peremptory norm / jus cogens, sehingga imunitas negara tidak dapat diberikan.

i) Teori implied waiver. Menurut teori ini negara yang melakukan pelanggaran HAM yang berat dapat dianggap bahwa negara itu telah menanggalkan imunitasnya

Adapun argumen-argumen yang mendukung diberikannya imunitas sebagai berikut:

a. Tidak ditemukan aturan dalam hukum nasional maupun internasional yang melarang negara memberikan imunitas pada negara yang telah melakukan pelanggaran HAM yang berat.

b. Tidak ada the primary international instrument, yaitu Pasal 5 Universal Declaration of Human Rights, Pasal 7 The International Covenant on Civil and Political Rights, juga 
Pasal 2 dan 4 UN Convention Against Torture and Other Cruel, Inhuman and Degrading Treatment or Punishment juga Pasal 5 dan 12 UN Convention on Jurisdictional Immunities of States and Their Property yang mengatur mengenai hilangnya imunitas negara ketika terjaid pelanggaran HAM yang berat.

c. Pelanggaran HAM yang berat kaitannya adalah dengan tanggung jawab pidana individu bukan dengan imunitas negara menghadapai gugatan perdata individu.

d. Pendapat yang menyatakan bahwa imunitas kedudukannya di bawah jus cogens sehingga pelanggaran terhadap jus cogens (khususnya war crime) adalah null and void, negara otomatis tidak berhak atas imunitas adalah pendapat yang over dispositive.

\section{Konsekuensi Pelanggaran Jus cogens terhadap eksistensi imunitas negara}

Meskipun sebagaimana telah dipaparkan sebelumnya bahwa hierarkhi tidak begitu dikenal dalam hukum internasional, namun jus cogens sebagai norma tertinggi dalam hukum internasional sudah diterima secara umum oleh masyarakat bangsabangsa. Namun demikian, bagaimana efek pelanggaran jus cogens (seperti pelanggaran HAM yang berat) terhadap imunitas negara tidaklah pernah jelas. Kemungkinan adalah karena masing-masing telah berkembang bebas sendiri-sendiri. ${ }^{16}$

Dalam banyak kasus terkait hubungan antara imunitas negara dengan pelanggaran HAM yang berat nampak bahwa negara forum tetap memberikan imunitas pada negara asing di forum pengadilan nasionalnya sekalipun negara asing itu telah melakukan pelanggaran terhadap norma tertinggi dalam hukum internasional (peremptory norm).

Beberapa kasus dimaksud antara lain kasus Al Adsani v Kuwait yang diputus oleh Pengadilan Inggris dan European court on Human Right, Jones v Saudi Arabia yang diputus oleh Pengadilan Canada, McElhinney $v$ Ireland yang diputus Pengadilan Inggris serta Beozuri v Iran yang diputus oleh Pengadilan Amerika Serikat. Dari sekian banyak kasus termasuk empat kasus di atas nampak ada keseragaman berpikir para hakim. Semua hakim sepakat bahwa imunitas negara adalah adalah hak yang fundamental bagi suatu negara berdaulat yang merupakan perwujudan dari persamaan kedudukan dan kedaulatan negara. Sejak berabad-abad lampau dan masih terus berlangsung hingga kini, kedaulatan negara (sovereignty)

${ }^{16}$ Adam C. Belsky, Mark Merva, Naomi Roht-Arriaza, Implied Waiver Under THE FSLA: A Proposed Exception to Immunity for Violations of Peremptory Norms of International law, California Law Review, March, 1989, hlm.6 
diterima sebagai grundnorm dan inti sari dari hukum dan hubungan internasional. Hal ini dibuktikan dari adanya integritas territorial serta larangan intervensi satu negara terhadap negara lain. Di sisi lain mayoritas hakim juga berpandangan sama bahwa larangan penyiksaan dan pelanggaran berat HAM lainnya menduduki norma tertinggi (peremptory norm) dalam hukum internasional. Peremptory norm adalah non derogable, tidak dapat disimpangi, tidak dapat dimodifikasi atu diubah selain oleh ketentuan lain yang memiliki kedudukan setara.

Menghadapi masalah imunitas negara sebagai hak yang mendasar dan merupakan hukum kebiasaan internasional yang sudah diakui sejak berabad-abad lampau. Di satu sisi, serta kenyataan adanya larangan melakukan pelanggaran HAM yang berat yang berstatus sebagai jus cogens di sisi lain, praktek beberapa pengadilan menunjukkan bahwa mereka mengutamakan imunitas negara.

Dalam pengadilan kasus Bouzari pengadilan banding Canada menegaskan bahwa pengadilan mengakui status peremptory dari larangan penyiksaan di bawah hukum internasional, juga mengakui adanya keutamaan jus cogens atas imunitas negara. Meskipun demikian, secara tegas pula pengadilan menolak memberlakukan pelanggaran HAM yang berat sebagai perkecualian dalam undang-undang nasional mereka tentang imunitas negara asing di pengadilan nasional. Hakim dalam kasus ini melihat bahwa praktek negara-negara senantiasa memberikan imunitas pada negara perpetrator atau pelaku pelanggaran HAM yang berat. Dalam kasus Jones pengadilan Inggris menyatakan bahwa pelanggaran jus cogens tidak otomatis menghapuskan imunitas. Meskipun memberikan imunitas hakim nenegaskan bahwa tidak berarti pengadilan Inggris mendukung atau melegitimasi tindakan pelanggaran HAM yang berat. Akhir kata dapat disimpulkan, bahwa mayoritas hakim dalam kasus-kasus yang memberikan imunitas menyetujui bahwa jus cogens tidak menimbulkan konsekuensi hukum pada imunitas negara. Mayoritas pengadilan menyatakan tidak adaya bukti dalam hukum internasional bahwa negara mengakui atau memberikan efek jurisdiksi universal atas pelanggaran jus coges yang dilakukan negara. Dinyatakan pula tidak ada larangan untuk memberikan imunitas negara pada negara asing sekalipun negara ini melakukan pelanggara jus cogens. Hal ini nampak dalam Konvensi menentang penyiksaan yang tidak memuat aturan larangan memberikan imunitas pada negara perpetrator prinsip sovereign immunity tetap tidak dapat diganggu gugat dalam hukum internasional, tidak tunduk pada perkecualian untuk kejahatan internasional yang berat (grave international crimes). 
Dapat ditambahkan pula bahwa ada kekhawatiran para diri para hakim bilamana mereka mengabaikan atau mengingkari imunitas negara asing di depan pengadilan nasional. Kekhawatiran itu antara lain kerusakan hubungan baik antara negara forum dengan negara perpetrator serta kekawatiran akan membanjirnya tuntutan terhadap negara asing di negara forum.

Kekawatiran ini menurut Alexander Orakhhelashvili sangatlah berlebihan dan merupakan pemikiran hakim yang tradisional atau orthodox. ${ }^{17}$ Tidak pernah ada bukti bahwa pengingkaran imunitas pada negara perpetrator berdampak pada rusaknya hubungan kedua negara secara serius, dalam jangka waktu lama dan tidak dapat diperbaiki. Selanjutnya pengingkaran imunitas justru akan menjadi sarana pencegahan negara melakukan pelanggaran berat agar tidak diadili di forum negara lain. $^{18}$

Apa yang dikemukakan Alexander Orakhelashvili didukung fakta bahwa sejak 1945 hukum HAM berkembang pesat dan mendominasi aturan-aturan hukum internasional. Ada 2 perkembangan besar hukum HAM sejak 1945. Pertama, masyarakat internasional mengakui adanya norma lain yang menjadi pesaing norma kedaulatan. Norma-norma HAM ini termasuk di antaranya hak bebas dari penyiksaan (torture) dan tindakan kejam lainnya, tidak berperikemanusiaan atau perlakuan buruk yang merendahkan derajat manusia, hak untuk hidup, juga larangan genocida. Norma-norma HAM itu memperoleh status jus cogens, non derogable obligation yang mengikat semua negara. Kedua, berbagai lembaga seperti pengadilan nasional dan internasional sudah menerapkan norma HAM untuk melawan norma kedaulatan negara. Mereka sudah menjatuhkan sanksi tanggung jawab perdata serta pidana pada pejabat pemerintah yang melakukan pelanggaran HAM yang berat. $^{19}$

Suatu norma hierarkhi secara bertahap sudah mulai dikembangkan dalam hukum internasional, sebagaimana Prospher Weil nyatakan dalam pemikirannya tentang relative normativity. Masalah kedaulatan negara adalah masalah yang berkaitan dengan pemeliharaan stabilitas sistem internasional dan memajukan

${ }^{17}$ Alexander Orakhelashvili, "State Immunity and Hierarchy of Norms: Why The House of Lords Got it Wrong”, Symposium :State Immunity in Civil Proceedings for Serious Violations of Human Rights, 18 EURJIL 955, European Journal of International Law, November, 2007, hlm. 2

${ }^{18}$ Ibid., hlm.3

${ }^{19}$ William J Aceves, Relative Normativity,: Challenging The Sovereignty norm through Human Rights Litigation, Hasting International, and Comparative Law Review, Summer 2002, hlm. 1 
hubungan damai antar negara. Tetapi, HAM adalah juga suatu masalah yang tidak kalah pentingnya. Ketika norma kedaulatan digunakan untuk menutupi pelanggaran HAM, harus digaris bawahi penempatannya dalam norma hierarkhi. ${ }^{20}$

ICTY dan Pengadilan khusus untuk Sierra Leone sudah menegaskan bahwa amnesti-amnesti untuk tindakan yang bertentangan dengan jus cogens adalah tidak menimbulkan akibat hukum. ${ }^{21}$ Selanjutnya Komisi Hukum Internasional PBB menegaskan adanya perluasan jus cogens dalam hukum tanggung jawab negara sebagaimana ditegaskan dalam Pasal 40 -41 Draft Articles on State Responsibility yang mewajibkan negara-negara untuk tidak mengakui tindakan pelanggaran jus cogens. ${ }^{22}$ Fungsi norma tertinggi atau peremprory norm adalah untuk mencegah impunitas terhadap pelaku pelanggaran HAM yang berat.

Pengadilan Itali dan Yunani telah mengakui keutamaan jus cogens dibanding state immunity. Negara yang melakukan pelanggaran jus cogens diangap telah menanggalkan imunitasnya. Segala tindakan pelanggaran jus cogens adalah batal demi hukum dan pelakunya tidak dapat mendapatkan keuntungan atau manfaat dari keberadaan suatu prinsip atau aturan hukum seperti prinsip imunitas. Hal ini selaras dengan prinsip ex injuria jus non oritur yang diakui dalam hukum internasional.

Pengadilan Itali menyatakan ketidaksetujuannya pada pendapat yang menyatakan bahwa imunitas negara dengan jus cogens adalah dua bangunan yang terpisah. Menurut pengadilan norma hukum tidak dapat diinterpretasikan bebas, terlepas sama sekali (independent) dari aturan yang lain, karena semua norma hukum itu saling bergantung, saling mengisi, melengkapi satu sama lain dan saling memepengaruhi satu sama lain dalam penerapannya. Beberapa interaksi antar norma hukum menyebabkan pengakuan adanya perkecualian terhadap penerapan imunitas negara. Contoh adalah adanya pemberian kedudukan superior norm atau jus cogens pada norma-norma tertentu yang penting untuk menjaga atau memelihara nilai-

${ }^{20}$ Louis Henkin, 1999:34

${ }^{21}$ The Prosecutor v. Furundzija, Judgment of 10 Dec. 1998, IT-95-17/I-T, at para. 155; Prosecutor v. Morris Kallon \& Brimma Bazzy Kamara, SCSL-2004- 15-AR72(E) \& SCSL-2004-16-AR72(E), Decision of 13 Mar. 2004, at para. 71; Prosecutor v. Augustine Gbao, SCSL-2003-01-I, Decision of 31 May 2004, at para. 9.

${ }^{22}$ Secara lengkap Pasal 40 menetapkan sebagai berikut:

1. This chapter applies to the international responsibility which is entailed by a serious breach by a State of an obligation arising under a peremptory norm of general international law.

2. A breach of such an obligation is serious if it involves a gross or systematic failure by the responsible State to fulfil the obligation. Selanjutnya Pasal 41 menetapkan sebagai berikut:

1. States shall cooperate to bring to an end through lawful means any serious breach within the meaning of article 40.

2. No State shall recognize as lawful a situation created by a serious breach within the meaning of article 40, nor render aid or assistance in maintaining that situation. 
nilai esensial pada keseluruhan masyarakat internasional. Pengadilan juga menambahkan bahwa pengingkaran imunitas merupakan kepatuhan terhadap apa yang sudah ditetapkan dalam Pasal 41 ILC draft tentang tanggung jawab negara 2001 untuk tidak mengakui tindakan pelanggraan jus cogens serta tidak membantu negara yang sudah melakukan pelanggaran jus cogens. ${ }^{23}$

Kedua pengadilan, Yunani dan Itali telah mengkombinasikan teori hierakhi normatif dengan efek jus cogens di bidang pengakuan. Memberikan imunitas akan berarti mengakui hasil dari suatu pelanggaran jus cogens yang dilakukan negara perpetrator dan membantu negara pelaku dalam mengkonsolidasikan hasilnya. Pasal 41 mensyaratkan negara untuk tidak mengakui sebagai tindakan yang sah kondisi yang dihasilkan dari pelanggaran jus cogens. Jus cogens secara langsung akan mensyaratkan kedua pengadilan mengingkari imunitas dan keduanya patuh pada persyaratan itu. Meskipun pengadilan kasus Ferini dikritik karena mengadili negara asing tanpa persetujuannya. ${ }^{24}$

Namun hal ini dapat disanggah dengan argumen bahwa pengadilan terhadap negara asing di depan pengadilan nasional dalam kasus-kasus komersial juga tidak pernah mensyaratkan persetujuan dari negara-negara asing itu sebelumnya.

Untuk menyatakan dampak pelanggaran jus cogens terhadap imunitas negara pengadilan pada kasus Al-Adsani, Jones dan Bouzari menyatakan bahwa antara imunitas negara dengann jus cogens adalah terpisah satu sama lain. Jus cogens adalah masalah substantif adapun imunitas negara adalah masalah procedural sehingga tidak ada hubungan satu sama lain dengan demikian pelanggaran terhadap jus cogens tidaklah memiliki pengaruh pada imunitas negara. Pendapat ini memiliki beberapa kelemahan. Pertama, hukum internasional tidak pernah menarik batas atau memisahkan antara norma substantif dan prosedural. Semua norma hukum internasional berasal dari kesepakatan negara-negara atau penerimaan oleh masyarakat internasional secara keseluruhan, dan karenanya tidak ada kriteria yang pernah ditetapkan atau perwakilan yang diakui untuk memisahkan keduanya. Bahkan jika imunitas adalah prosedural pada level nasional, di bawah hukum internasional ini tetap adalah norma seperti yang lain dan dapat konflik dengan norma tertingi (peremptory norms) seperti pelanggaran HAM yang berat. Tidak ada

\footnotetext{
${ }^{23}$ De Sena and De Vittor, 'State Immunity and Human Rights: The Italian Supreme Court Decision on the Ferrini Case', 16 EJIL 2005, p. 89; Bianchi, Case-note on Ferrini, 99 AJIL 2005, p. 242

${ }^{24}$ Fox, 'State Immunity and the International Crime of Torture' [2006] EHRLR 142, at., p. 144.
} 
keharusan prosedural khusus dalam penerapan jus cogens ke dalam hukum nasional karena larangan melakukan pelanggaran HAM yang berat seperti penyiksaan misalnya sudah melekat menjadi kewajiban negara forum yang harus dilaksanakan. Apabila negara forum tidak dapat melaksanakannya dalam arti melakukan penegakan hukum maka ia harus memberikannya pada negara forum lain yang mampu untuk melaksanakan atau menegakkannya. Kedua, jus cogens, berbeda dengan norma yang lain, tidak dibatasi pada masalah substantial, yang mendasar adalah untuk menerapkan konsekuensi hukum akibat pelnaggaran norma tertinggi itu. Pasal 53 dan 71 Konvensi Wina 1969 tidak menetapkan persyaratan substantive tetapi mengatur konsekuensi hukum apabila terjadi pelanggaran terhadap jus cogens. Hal yang sama dapat ditemukan dalam Pasal 41 ILC draft articles tentang tanggung jawab negara yang memberikan kewajiban untuk tidak mengakui tindakan-tindakan pelanggaran jus cogens. Ketiga, secara umum telah diterima bahwa karakter prosedural imunitas tidak dapat mencegah penegakan hukum untuk kejahatan-kejahatan internasional seperti pelanggaran HAM yang berat. Keempat, sudah diterima pula bahwa tindakan-tindakan pelanggaran HAM yang berat seperti penyiksaan (torture), penghilangan paksa (disappearance), juga kejahatan perang, baik karena statusnya sebagai jus cogens maupun sifat horrendous-nya, tidak dapat dikategorikan sebagai tindakan iure imperii atau tindakan pihak yang berdaulat (sovereign right), sehingga pembedaan antara masalah substantial dan prosedural tidaklah relevan. Akhirnya apa yang disebut sebagai pembedaan antara norma substansi dan prosedural haruslah ditolak karena akan berakibat pada pemberian impunitas. Meskipun doktrim imunitas tidak sama dengan impunitas, karena sebagaimana dikatakan pengadilan-pengadilan kasus Al-Adsani, Jones dan Bouzari karena yang pertama adalah substansial dan yang kedua adalah prosedural tetapi realita yang terjadi membuktikan yang lain karena korban yang berhadapan dengan imunitas negara tidak memiliki pilihan lain untuk membela hak-hak mereka dan kenyataannya mereka tidak pernah mendapatkan remedi apapun. Demikian halnya sang perpetrator tidak pernah mendapatkan hukuman. (Bouzari (CA), supra note 21, at paras 86-88, Jones (HL), supra note 2, at para. 24 (per Lord Bingham).) Mengakui tindakan pelanggaran HAM yang berat sebagai tindakan pihak yang berdaulat (sovereign right) sama saja dengan mengakui negara pelaku beserta pejabatnya legal security yang absolut, dan mengabaikan hak korban mendapatkan remedi. Dengan putusannya memberikan imunitas dapat disimpulkan bahwa Pengadilan sama saja dengan 
mendorong terjadinya impunitas, mengakui keabsahan tindakan pelanggaran HAM, suatu hal yang bertentangan dengan kewajiban dalam Pasal 41 ILC draft tentang Tanggung Jawab negara.

\section{Penutup}

Dari permasalahan yang telah diteliti dan diuraikan di atas, dapat disimpulkan sebagai berikut:

1. Imunitas negara di depan forum pengadilan nasional negara asing merupakan hak yang fundamental bagi setiap negara yang berdaulat. Hal ini merupakan implementasi dari prinsip persamaan kedaulatan dan non intervensi dalam hukum internasional.

2. Masih banyak pengadilan nasional yang memberikan imunitas pada negara asing meskipun negara tersebut melakukan pelanggaran HAM yang berat. Dari hasil kajian penulis dapat disimpulkan bahwa alasan yang digunakan adalah sebagai berikut:

a. Kekawatiran akan mengancam hubungan baik kedua negara;

b. Kekawatiran akan membanjirnya tuntutan terhadap negara tersebut di forum pengadilan nasional negara lain;

c. Tidak ditemukan aturan dalam hukum nasional maupun internasional yang melarang negara memberikan imunitas pada negara yang telah melakukan pelanggaran HAM yang berat.

d. Tidak ada the primary international instrument, yaitu Pasal 5 Universal d Declaration of Human Rights, Pasal 7 The International Covenant on Civil and Political Rights, juga Pasal 2 dan 4 UN Convention Against Torture and Other Cruel, Inhuman and Degrading Treatment or Punishment juga Pasal 5 dan 12 UN Convention on Jurisdictional Immunities of States and Their Property yang mengatur mengenai hilangnya imunitas negara ketika terjaid pelanggaran HAM yang berat.

e. Pelanggaran HAM yang berat kaitannya adalah dengan tanggung jawab pidana individu bukan dengan imunitas negara menghadapai gugatan perdata individu

f. Antara imunitas kedaulatan dengan pelanggaran HAM yang berat adalah dua hal yang berbeda dan terpisah sama sekali sehingga pendapat yang menyatakan bahwa imunitas kedudukannya di bawah jus cogens adalah null and void, 
3. Keberadaan norma hierarkhi sangatlah penting dalam hukum internasional. Pengakuan adanya jus cogens, peremptory norm membutuhkan kejelasan lebih lanjut dalam hukum internasional. Masih banyak putusan pengadilan nasional yang tidak mengakui adanya efek hukum terhadap imunitas kedaulatan meskipun suatu negara melakukan pelanggaran jus cogens seperti pelanggaran HAM yang berat. Dengan demikian menurut peneliti sangat dibutuhkan suatu proses yang terkadang cukup panjang dalam hukum internasional untuk terjadinya suatu perubahan. Saat ini perubahan itu sudah dimulai meskipun belum dapat diterima sepenuhnya oleh seluruh masyarakat internasional. Perubahan yang dimaksud antara lain;

a. Keberadaan Pasal 12 Konvensi tentang imunitas negara 2004;

b. Keberadaan Pasal 40 dan 41 draft articles Konvensi tentang tanggung jawab negara yang mewajibkan negara untuk tidak mengakui tindakan yang lahir dari pelanggaran terhadap norma jus cogens;

c. Adanya amandemen yang dilakukan beberapa negara dalam undang-undang tentang imunitas negara asing di depan pengadilan nasional mereka yang tidak memberikan imunitas ketika negara asing itu melakukan pelanggaran jus cogens seperti pelanggaran HAM yang berat.

d. Adanya putusan beberapa pengadilan nasional yang tidak memberikan imunitas pada negara asing dalam kasus pelanggaran HAM yang berat.

Peneliti menyarankan sebagai berikut:

1. perlu diatur lebih lanjut masalah hierarchi norm dalam suatu instrumen hukum internasional

2. perlunya semua negara memiliki aturan mengenai imunitas negara asing dalam hukum nasionalnya

\section{Daftar Pustaka}

A. Bianchi, Cf., 'Denying State Immunity to Violators of Human Rights', dalam 46 Austrian Journal of Public and International Law (1993/94) 1995

Al-Adsani v United Kingdom, App. No.35763/97, November, 21, 2001, http:// www.echr.coe.int/eng/judgments, htm

Brownlie, Principles of Public International Law, 4th ed. Oxford, Clarendon Press, 1990

C. Belsky, Adam, Mark Merva , Naomi Roht-Arriaza , Implied Waiver Under THE FSIA: A Proposed Exception to Immunity for Violations of Peremptory Norms of International law, California Law Review, March, 1989 
Caplan. 'State Immunity, Human Rights, and Jus Cogens: A Critique of the Normative Hierarchy Theory', American Journal of International Law 2003

de Wet, Erika, The international constitutional Order, 55 ICLQ 51, International $\mathcal{E}$ Comparative Law Quarterly, January, 2006

Dixon, Martin, Textbook on International Law, fourt edition, Blackctone Press Limited, London, United Kingdom, 2000

Dugard, John, Recognition and The United Nations, 1987

F. Sallows, Ariel, Saskatchewan Law Review, 2002

Franck, T.M., "Legitimacy in the International System” (1988) 82 of International Human Rights" (1986) 80 American Journal of InternationalLaw

Fogarty v UK, App no 37112/97, Judgment [GC], 21 Nov 2001

Forrest Martin, Francisco, Delineating a Hierarchical Outline of International Law Sources and Norms, Saskatchewan Law Review, 2002

Gattini, Andrea, “The Right of War Crime Victim to Compensation before National Court: War crimes and State Immunity in the Ferrini Decision : Note and Comment " dalam Journal of International Criminal Justice March, 2005

Henkin, Louis, That's worl: sovereignty, and globalization, and human rights, et cetera, 68 Fordham L. Review. I, 1999

Humes-Schulz, Stacy, Limiting Sovereign Immunity in The Age of Human Rights, Harvard Human Rights Journal, 21 HVHRJ 105, Winter 2008

J. Aceves, William, Relative Normativity,: Challenging The Sovereignty norm through Human Rights Litigation,, Hasting International, and Comparative Law Review, Summer 2002

Kaczorowska, Alina, "Public International Law, London, Old Bailey Press, 2002,

Koskenniemi, M., “Hierarchy in International Law: A Sketch” (1997) 8 E.J.I.L. 566 at 567, online: European Journal of International Law <http:// www.ejil.org/journal/ Vo18/No4/art2.html> (last modified: 9 November 1999).

McGregor, Lorna, State Imuunity and Jus Cogens, 2005

McCorquodale, Robert, dan Martin Dixon,2003:, Cases and Materials on International Law, fourth edition, Ocford University Press

McElhinney v Ireland, App no 31253/96, Judgment [GC], 21 Nov 2001. 〈http:// www.hudoc.echr.coe.int>.

Meron, T., “On a Hierarchy of International Human Rights” (1986) 80 American Journal of International Law

Orakhelashvili, A. 'State Immunity and International Public Order', 45 German Yearbook of International Law (2002) 227

O'Connell, International Law, Vol II, 2th edition, Stevens \& Sons Ltd, London, 1970 
Pasquale De Sena and Francesca De Vittor, "State Immunity and Human Rights: The Italian Supreme Court Decision on the Ferrini Case", The European Journal of International Law (EJIL), Vol. 18 No. I

R. Helfer, Laurence, 193 Constitutional analogies in the international legal system, Loyola of Los Angeles Law Review, Fall 2003

Riesenfeld, Jus Dispositivium and Jus Cogens in International Law: In the Light of a Recent Decision of the German Supreme Constitutional Court, 60 AM. J. INT'L L. 511, 513 (1966)

Rozakis, C.L., "The Concept of Jus Cogens in the Law of Treaties, Amsterdam”, NorthHolland, 1979

S. Mitchell, David "The prohibition of rape in international humanitarian law as a norm of jus cogens clarifying the doctrine, Duke Journal of Comparative and International Law" Spring-Summer 2005

Shelton, Dinah, "International Law and relative Normativity" dalam Evans, Malcolm D, International Law, 2003, Oxford Universiy Press, first edition

Simma \& Alston dalam “The Sources of Human Rights Law: Custom, Jus cogens, and General Principles, in HUMAN RIGHTS LAW (Philip Alston ed, 1996)

Starke, JG, Pengantar Hukum Internasional, Edisi kesepuluh, Buku I, dialih bahasakaan oleh Bambang Iriana Djajatmmaadja, Sinar Grafika, Jakarta, 1992

Turpel \& Sands, Peremptory International Law and Sovereignty: Some Questions, 3 CONN. J. INT'L. L. 364, 365 (1988).

Valparaiso University Law Review Fall, 1998. Diiscrimination among Rights?: A Nation's Legislating a Hierachy of Human rIghts in the Context of International Human rights Customary law

Wouters, J., 'The Judgment of the International Court of Justice in the Arrest Warrant Case: Some Critical Remarks', 16 Leiden Journal of International Law (2003)

Wirth, Steffen, Immunity for core crimes? The ICJ"S Judgment in the Congo_belgium Case, European Journal of International Law, 13 Eur. J. Int'1 L. 877, September, 2002

Yudha Bhakti, “Pengertian Jus Cogens Dalam Konvensi Wina 1969 Tentang Hukum Perjanjian", dalam Majalah Padjadjaran, No I, 1981, FH Univeritas Padjadjaran, Bandung. 